\title{
PENGARUH SELF ASSESSMENT SYSTEM, MONEY ETHICS, DAN TEKNOLOGI DAN INFORMASI PERPAJAKAN TERHADAP PERSEPSI WAJIB PAJAK BADAN MENGENAI TAX EVASION (STUDI KASUS PADA KPP PRATAMA LANGSA)
}

\author{
Razif $^{1}$ \\ razifishak@gmail.com
}

Alqonitur Rasyidah ${ }^{2}$

rasyidah12man@gmail.com

\author{
${ }^{1}$ Dosen FEB Akuntansi Universitas Malikussaleh Lhokseumawe \\ ${ }^{2}$ Program Studi Akuntansi FEB Universitas Malikussaleh Lhokseumawe
}

\begin{abstract}
This study aims to determine and analyze the influence of self-assessment system, money ethics, and technology and tax information on corporate taxpayer perception of tax evasion in KPP Pratama Langsa. The data used in this study is the primary data. The sample of this study is taken using purposive sampling. The sample in this research is 45 taxpayer of the construction agency registered in KPP Pratama Langsa. Data analysis method used is multiple linear regression analysis and processed using statistical program SPSS 22.0. The results showed that the self-assessment system has a negative and significant effect on corporate taxpayer perception of tax evasion, money ethics and technology and taxation information have a positive and significant effect on the corporate taxpayer perception of tax evasion in KPP Pratama Langsa.
\end{abstract}

Keywords: Self-assessment System, Money Ethics, Technology and Tax Information, Tax Evasion. 


\section{PENDAHULUAN}

Pajak merupakan sumber utama pendapatan negara yang digunakan untuk membiayai pengeluaran negara baik rutin maupun pembangunan (Resmi, 2013). Sebagai sumber keuangan negara, pemerintah berupaya meningkatkan penerimaan uang sebanyak-banyaknya melalui sektor pajak. Peningkatan penerimaan kas negara melalui sektor pajak tersebut diperuntukkan untuk meningkatkan kesejahteraan.

Penerimaan pajak dalam beberapa tahun terakhir terus mengalami peningkatan dari tahun ke tahun, namun realisasi penerimaan pajak dengan target penerimaan pajak yang telah ditetapkan oleh pemerintah masih belum sepenuhnya tercapai. Pada tahun 2017 target penerimaan pajak yang telah ditetapkan pemerintah adalah Rp. $\quad 1.472,7$ triliun sedangkan realisasi penerimaan pajak mencapai Rp. 1.339,8 triliun dengan persentasi penerimaan pajak sebesar $91 \%$.

Wajib pajak adalah individu atau orang atau suatu badan usaha yang merupakan subyek pajak yang menurut peraturan perundang-undangan dalam hal perpajakan ditentukan untuk melakukan kewajiban perpajakan termasuk di dalamnya pemotong pajak atau pemungutan pajak tertentu. Wajib Pajak Badan meliputi pembayaran pajak, pemotongan pajak, yang mempunyai hak dan kewajiban perpajakan sesuai dengan ketentuan dan peraturan perundang-undangan perpajakan (Rosdiana dan Irianto, 2011). Badan adalah sekumpulan orang dan/atau modal yang merupakan kesatuan baik yang melakukan usaha. Badan meliputi Perseroan Terbatas (PT), Perseroan Komanditer (CV), perseroan lainnya, Badan Usaha Milik Negara maupun Daerah (BUMN/D) dengan nama dan dalam bentuk apapun, firma, kongsi, koperasi, dana pensiun, persekutuan, perkumpulan, yayasan, organisasi massa, organisasi sosial politik, atau organisasi lainnya.

Tax Evasion (penggelapan pajak) merupakan usaha yang digunakan oleh wajib pajak untuk mengelak dari kewajiban yang sesungguhnya, dan merupakan perbuatan yang melanggar undang-undang pajak. Misalnya wajib pajak tidak melaporkan pendapatan yang sebenarnya, Siahaan dalam Rachmadi (2014). Tindakan tax evasion (penggelapan pajak) adalah perbuatan melanggar Undang-Undang Perpajakan, dengan menyampaikan Surat Pemberitahuan Tahunan (SPT) dengan jumlah penghasilan yang lebih rendah daripada yang sebenarnya (understatement of income) di satu pihak dan atau melaporkan biaya yang lebih besar dibandingkan yang sebenarnya (overstatement of the deductions) di lain pihak. Tindakan taxevasion dapat dilihat dari beberapa kriteria yaitu wajib pajak tidak melaporkan harta yang sesungguhnya, membayar beban pajak terutang tidak sesuai yang telah dibebankan, dan yang lebih parah adalah tidak melaporkan SPT (Sari, 2015).

Penggelapan pajak dapat diakibatkan oleh sistem perpajakan (McGee et al., 2008). Sunarsip (Ipotnews, 2012) mengungkapkan, adanya perbedaan penafsiran antara wajib pajak (WP) yang menerapkan Self Assessment System dengan Direktorat Jenderal Pajak mengenai besaran nilai pajak yang harus dibayar menjadi pemicu utama terjadinya kejahatan perpajakan. Keberhasilan Self Assessment System tidak akan tercapai tanpa adanya kerja sama antara petugas pajak dengan wajib pajak. Sistem ini akan berjalan baik bila masyarakat memiliki tingkat kesadaran perpajakan secara sukarela (voluntary tax compliance) yang tinggi. Apabila tingkat kesadaran wajib pajak masih rendah, dapat menimbulkan berbagai macam masalah perpajakan, salah satunya yaitu penggelapan 
pajak (tax evasion) (Suminarsasi dan Supriyadi, 2014).

Tujuan atau alasan para wajib pajak melakukan tax evasion tersebut dapat dipengaruhi oleh kecintaan terhadap uang yang tinggi karena menurut Sloan (2002) kecintaan terhadap uang atau "the love of money" adalah keinginan manusia terhadap uang atau keserakahan. Alasan lain yang mendukung adalah ketika seseorang menempatkan uang sebagai prioritas utama dalam kehidupan sehari-harinya, mereka akan merasa bahwa tax evasion adalah tindakan yang dapat diterima (Lau, Choe, dan Tan, 2013). Orang-orang yang memiliki kecintaan terhadap uang yang sangat tinggi secara mental lebih banyak terlibat dalam perilaku tidak etis dalam organisasi (Tang $\&$ Chiu, 2003) karena mereka termotivasi untuk mendapatkan lebih banyak uang. Menurut Tang (2002) money ethics berhubungan secara langsung dengan perilaku tidak etis. Hal ini dapat diartikan bahwa semakin seseorang memprioritaskan uang sebagai hal yang penting (high money ethics), orang tersebut lebih cenderung untuk melakukan tindakan tax evasion yang tidak etis daripada orang yang low money ethics.

Ditjen Pajak telah melakukan beberapa reformasi perpajakan dan modenisasi administrasi perpajakan. Modernisasi lebih lanjut ditandai dengan penerapan teknologi informasi terkini dalam pelayanan perpajakan seperti online payment, e-SPT, e-filling, e-registration, e-billing. Modernisasi layanan perpajakan yang dilakukan pemerintah diharapkan dapat mempermudah wajib pajak dalam melakukan kewajiban perpajakannya, sehingga dapat meminimalisasi tindakan tax evasion.

Berikut ini contoh beberapa fenomena yang pernah terjadi dalam hal kasus tax evasion (Penggelapan Pajak). Dalam penelitian yang dilakukan oleh
Santana, dkk (2015) yang menjelaskan adanya kasus pengusaha retail yang melakukan penggelapan pajak di Bukittinggi. Berdasarkan data dari Dirjen Pajak, pada tahun 2011 ditemukan 23 kasus dengan kerugian Rp 194 miliar, pada tahun 2012 terdapat 12 kasus dengan kerugian Rp 326 miliar serta pada tahun 2013 ditemukan 20 kasus dengan kerugian negara mencapai Rp 239 miliar (www.beritasatu.com).

Selain itu tindakan penggelapan pajak juga pernah dilakukan oleh mantan manajer pajak PT Asian Agri Group yaitu Suwir Laut alias Liu Che Siu Pada tahun 2012 yang terbukti melakukan penggelapan pajak dengan tindak pidana menyampaikan surat pemberitahuan dan/atau keterangan dengan isi tidak benar atau tidak lengkap secara berlanjut selama berturut-turut empat tahun yaitu [ada tahun 2002 hingga 2005 terhadap sejumlah 14 perusahaan senilai Rp. $\quad 1,259 \quad$ triliun (www.mongabay.co.id).

Fenomena yang terjadi pada Kantor Pelayanan Pajak Pratama Langsa umumnya tidak berbeda jauh dengan apa yang terjadi di beberapa wilayah lain di Indonesia. Wajib pajak cenderung untuk membayar kewajiban perpajakannya sekecil mungkin. Self assessment system yang belum terlaksana dengan baik seperti masih ada penunggakan pajak yang dilakukan oleh wajib pajak, wajib pajak yang tidak melaporkan kewajiban pajaknya dan ada yang tidak menyampaikan pajaknya dengan tidak benar. Masih ada wajib pajak yang memiliki money ethics yang tinggi sehingga wajib pajak tidak melakukan kewajiban perpajakannya. Penerapan tekonologi dan informasi perpajakan dalam pelayanan perpajakan di KPP Pratama Langsa dapat mempermudah wajib pajak dalam melakukan kewajiban perpajakannya, sehingga dapat meminimalisasi tindakan tax evasion. Salah satu kasus di Langsa yaitu adanya PT. A yang bergerak di bagian kontruksi melakukan kerja sama dengan PT. 
B. Setelah semua kegiatan belanja barang kontruksi itu selesai, PT. A menerbitkan faktur dan diberikan ke PT. B. Tetapi setelah diterbitkannya faktur, PT. B tidak melakukan kewajibannya atau dengan kata lain tidak membayar kewajibannya dengan sepenuhnya. Akibat dari tindakan yang dilakukan PT. B, pastinya akan merugikan negara (Deny, 2017).

Adapun rumusan masalah dalam penelitian ini adalah: 1. Apakah Self Assessment System berpengaruh terhadap persepsi wajib pajak badan mengenai Tax Evasion. 2. Apakah Money Ethics berpengaruh terhadap persepsi wajib pajak badan mengenai Tax Evasion. 3. Apakah Teknologi dan Informasi Perpajakan berpengaruh terhadap persepsi wajib pajak badan mengenai Tax Evasion. 4. Apakah Self Assessment System, Money Ethics, dan Teknologi dan Informasi Perpajakan berpengaruh terhadap persepsi wajib pajak badan mengenai Tax Evasion.

Sedangkan tujuan penelitian adalah

1. Untuk menganalisis pengaruh self assessment system terhadap persepsi wajib pajak badan mengenai tax evasion. 2. Untuk menganalisis pengaruh money ethics terhadap persepsi wajib pajak badan mengenai tax evasion. 3. Untuk menganalisis pengaruh teknologi dan informasi perpajakan terhadap persepsi wajib pajak badan mengenai tax evasion. 4. Untuk menganalisis pengaruh self assessment system, money ethics, tekonologi dan informasi perpajakan terhadap persepsi wajib pajak badan mengenai tax evasion.

\section{TINJAUAN PUSTAKA}

\section{Atribution Theory (Teori Atribusi)}

Teori ini menggambarkan suatu komunikasi seseorang yang sedang berusaha untuk menelaah, menilai serta menyimpulkan penyebab dari suatu kejadian menurut persepsi individu. Pada dasarnya, teori atribusi ini menyatakan bahwa bila individu-individu mengamati perilaku seseorang mereka mencoba untuk menentukan apakah ini ditimbulkan secara internal atau eksternal. Perilaku yang disebabkan secara internal adalah perilaku yang diyakini berada di bawah kendali pribadi individu itu sendiri, misalnya kemampuan, pengetahuan atau usaha. Sedangkan perilaku yang disebabkan secara eksternal adalah perilaku yang dipengaruhi dari luar artinya individu akan terpaksa berperilaku karena situasi, misalnya keberuntungan, kesempatan, dan lingkungan (Robbins dalam Dewinta, 2012).

\section{DEFINISI PAJAK}

Menurut Kementerian Keuangan Republik Indonesia DJP dalam bukunya Lebih Dekat Dengan Pajak (2013:2), yaitu "pajak adalah kontribusi wajib kepada Negara yang terutang oleh orang pribadi atau badan yang bersifat memaksa berdasarkan undang-undang dengan tidak mendapatkan imbalan secara langsung dan digunakan untuk keperluan negara bagi sebesar-besarnya kemakmuran rakyat".

Menurut Kementerian Keuangan Republik Indonesia DJP dalam bukunya Lebih Dekat Dengan Pajak (2013:2), Pajak merupakan sumber utama penerimaan Negara, tanpa pajak, sebagian besar kegiatan Negara tidak dapat dilaksanakan. Penggunaan uang pajak meliputi:

1. Pembayaran gaji aparatur Negara seperti Pegawai Negeri Sipil (PNS), Tentara Nasional Indonesia, dan Polisi Negara Republik Indonesia sampai dengan pembiayaan berbagai proyek pembangunan.

2. Subsidi Bahan Bakar Minyak (BBM), Subsidi Listrik, Subsidi Publik, Bantuan Langsung Sementara Masyarakat (BLSM) atau sejenisnya, Pengadaan Beras Miskin (Raskin), Jaminan Kesehatan Masyarakat (Jamkesmas). 
3. Pembangunan sarana umum seperti jalan-jalan, jembatan, sekolah, rumah sakit/puskesmas, kantor polisi.

Pembiayaan lainnya dalam rangka meningkatkan kesejahteraan bagi seluruh lapisan masyarakat.

\section{TAX EVASION}

Tax Evasion (penggelapan pajak) adalah tindakan wajib pajak yang selalu berusaha untuk membayar pajak yang terutang sekecil mungkin dan cenderung melakukan penyelundupan pajak yang tentunya melanggar peraturan perundangundangan (Rahayu, 2010:149).

Siahaan (2010) mengatakan bahwa penggelapan pajak membawa berbagai macam akibat, meliputi berbagai bidang kehidupan masyarakat, antara lain bidang keuangan, ekonomi, dan psikologi. Sedangkan, menurut Mardiasmo, (2013) mendifinisikan penggelapan pajak (tax evasion) adalah usaha yang dilakukan oleh wajib pajak untuk meringankan beban pajak dengan cara melanggar undangundang. Para wajib pajak sama sekali mengabaikan ketentuan formal perpajakan yang menjadi kewajibannya, memalsukan dokumen, atau mengisi data dengan tidak lengkap dan tidak benar.

Menurut Anwar (2013), Penggelapan pajak (tax evasion) adalah strategi dan teknik penghindaran pajak dilakukan secara ilegal dan tidak aman bagi wajib pajak dan cara penyeludupan pajak ini bertentangan dengan ketentuan perpajakan, karena metode dan teknik yang digunakan tidak berada dalam koridor undang-undang dan peraturan perpajakan. Resmi (2013), upaya menghindari pajak dengan cara ilegal adalah penggelapan pajak. Tindakan ini termasuk perbuatan kriminal, karena menyalahi aturan yang berlaku dan mencakup perbuatan sengaja tidak melaporkan secara lengkap dan jelas objek pajak.

\section{SELF ASSESSMENT SYSTEM}

Self Assessment System dikenal setelah terjadinya reformasi perpajakan pada tahun 1983 dimana sistem yang dipakai sebelumnya adalah Official Assessment System. Menurut Ilyas dan Burton (2012) Self Assessment System berarti kepada wajib pajak diberikan kepercayaan sepenuhnya untuk melaksanakan pemenuhan kewajiban perpajakannya dengan cara menghitung, memperhitungkan, menyetor dan melaporkan sendiri jumlah pajak yang harus dibayar ke negara. Rahayu (2010) menyatakan bahwa tata cara pemungutan pajak dengan menggunakan Self Assessment System berhasil dengan baik jika masyarakat mempunyai pengetahuan dan disiplin pajak yang tinggi, dimana ciri-ciri self assessment system adalah adanya kepastian hukum, sederhana perhitungannya, mudah pelaksanaanya, lebih adil dan merata, dan perhitungan pajak dilakukan oleh wajib pajak.

Menurut Ilyas dan Burton (2012), Prinsip Self Assessment System secara jelas tampak dalam ketentuan Pasal 12 UndangUndang No. 16 Tahun 1983 tentang Ketentuan Umum dan Tata Cara Perpajakan yang telah diubah dengan Undang-Undang No.16 Tahun 2009 (Undang-Undang KUP) pada dasarnya memiliki makna, yaitu:

1. Agar semua Wajib Pajak bersifat aktif di dalam melaksanakan kewajiban perpajakannya tanpa perlu menunggu adanya surat ketetapan pajak yang akan dikeluarkan oleh petugas pajak (fiskus),

2. Perhitungan jumlah pajak yang dibayar untuk sementara dianggap sebagai perhitungan menurut ketentuan yang berlaku,

Fiskus memiliki kewenangan untuk melakukan penghitungan jumlah pajak yang telah dilaporkan Wajib pajak sepanjanag fiskus memiliki data bahwa Wajib Pajak belum melaksanakan penghitungan dengan benar. Surat ketetapan pajak akan 
diterbitkan setelah melalui proses pemeriksaan dengan cara-cara yang diatur dalam undang-undang pajak.

Penelitian Suwandhi (2010) pada KPP Pratama Bandanung Cibeunying, menemukan pelaksanaan self assessment system berkaitan dengan signifikan dengan tindakan tax evasion pada KPP Pratama Bandung Cibeunying. Keterkaitan pelaksanaan self assessment system dengan tindakan tax evasion juga dipengaruhi oleh faktor lain yaitu kesadaran yang kurang tentang kewajiban membayar pajak, kondisi lingkungan, tarif pajak yang semakin tinggi, pelayanan fiskus yang mengecewakan.

Artinya, semakin baik pelaksanaan self asssessment system maka tindakan Tax Evasion yang terjadi akan semakin rendah. Demikian sebaliknya, semakin buruk pelaksanaan self assessment system maka tindakan tax evasion akan menjaddi tinggi. Sementara dalam persepsi wajib pajak atas pelaksanaan self assessment system masih cukup. Artinya pelaksanaan sistem yang dimulai dari pendaftaran NPWP, perhitungan pajak, penyetoran dan pelaporan SPT oleh wajib pajak pajak sendiri masih belum berjalan baik. Akan tetapi ada beberapa pelaksanaan yang sudah dianggap baik seperti proses pendaftaran dan pelayanan yang diberikan fiskus.

Dianutnya self assessment system diharapkan dapat menciptakan kesadaran diri wajib pajak dalam membayar pajak secara sukarela melalui misi dan konsekuensi yang dibawa oleh self assessment system, semakin tinggi kepatuhan sukarela maka semakin kecil pula kebutuhan mengawasi wajib pajak sehingga penggelapan pajak dapat diminimalisir.

$\mathrm{H}_{1}$ : self assessment system berpengaruh terhadap persepsi wajib pajak badan mengenai tax evasion
Money Ethics (etika uang) adalah pandangan seseorang terhadap uang. Seseorang yang memiliki etika uang (money ethics) yang tinggi atau disebut juga dengan cinta uang maka mereka akan meletakkan kepentingan yang lebih tinggi terhadap uang dan secara etika kurang peka dibandingkan orang yeng memiliki money ethics yang rendah.

Menurut Tang \& Chiu (2013) seseorang yang high love of money atau memiliki kecintaan terhadap uang yang tinggi lebih termotivasi untuk melakukan tindakan apapun demi memperoleh uang yang lebih banyak. Individu high love of money secara mental lebih banyak terlibat dalam perilaku tidak etis dalam organisasi daripada orang-orang yang low love of money.

The love of Money memiliki banyak arti secara subjek. Tang dan Luna-Acrocas (2004) mendefinisikan love of money sebagai: 1) pengukuran terhadap nilai seseorang atau keinginan akan uang tetapi bukan kebutuhan mereka; 2) makna dan pentingnya uang dan perilaku personal seseorang terhadap uang. Kemudian Tang, Chen, dan Sutarso (2008) mendefinisikan love of money sebagai perilaku seseorang terhadap uang; pengertian seseorang terhadap uang; keinginan dan aspirasi seseorang terhadap uang.

Lau, Choe, dan Tan (2013) menemukan hubungan yang positif antara money ethics dengan tax evasion. Ketika seseorang menekankan pada pentingnya uang dan memperoleh kekayaan, mereka akan merasa bahwa tax evasion dapat diterima. Seseorang yang sangat termotivasi oleh uang atau yang menempatkan yang sebagai prioritas utama akan percaya bahwa tax evasion adalah tindakan yang etis. Hal ini konsisten dengan penelitian sebelumnya yang menunjukkan bahwa money ethics memiliki dampak yang signifikan dan langsung terhadap perilaku yang tidak etis (Tang, 2002; Tang \& Chiu, 2003). Semakin 
tinggi tingkat kecintaan seseorang terhadap uang, maka semakin tinggi peluang seseorang yang melakukan tindakan tax evasion yang tidak etis.

$\mathrm{H}_{2} \quad$ : money ethis berpengaruh terhadap persepsi wajib pajak badan mengenai tax evasion.

\section{TEKNOLOGI DAN INFORMASI PERPAJAKAN \\ Menurut Ayu (2009) dalam} Ardyaksa (2014) teknologi dan informasi perpajakan merupakan teknologi dan informasi yang digunakan fiskus dalam membantu proses perpajakan. Modernisasi layanan perpajakan yang dilakukan pemerintah saat ini diharapkan dapat meningkatkan kualitas layanan, sehingga diharapkan kepatuhan wajib pajak dalam membayar pajak terhutangnya meningkat dikarenakan dipermudahkannya cara pembayaran dan pelaporan pajak.

Ditjen Pajak telah melakukan reformasi perpajakan dan modernisasi administrasi perpajakan berlandaskan case management. Seiring dengan itu, Ditjen Pajak juga melakukan kampanye sadar dan peduli pajak, pengembangan bank data dan Single Identification Number serta langkah-langkah lainnya yang sedang dan terus dikembangkan. Konsep modernisasi administrasi perpajakan pada prinsipnya adalah merupakan perubahan pada sistem administrasi perpajakan yang dapat mengubah pola pikir dan perilaku aparat serta tata nilai organisasi sehingga dapat menjadikan Direktorat Jenderal Pajak (DJP) menjadi suatu institusi yang profesional dengan citra yang baik di masyarakat.

Penelitian yang dilakukan oleh Permatasari (2013) dan Wahyuningsih (2013) mengenai minimalisasi tax evasion menunjukkan indikasi nilai negatif yang bersifat signifikan untuk variabel teknologi dan informasi perpajakan. Semakin tinggi dan modern teknologi dan informasi perpajakan yang digunakan, semakin tinggi tingkat tax evasion yang dilakukan. Adanya kemudahan teknologi dan informasi perpajakan mengakibatkan adanya oknumoknum yang ingin membobol data-data pajak (hacker). Sedangkan dalam penelitian Utami (2016) teknologi dan informasi perpajakan berpengaruh signifikan positif terhadap penggelapan pajak.

$\mathrm{H}_{3} \quad$ : teknologi dan informasi perpajakan terhadap persepsi wajib pajak badan mengenai tax evasion

\section{METODE PENELITIAN}

Populasi dalam penelitian ini adalah wajib pajak badan yang terdaftar di KPP Pratama Langsa. Teknik pengambilan sampel dalam penelitian ini adalah teknik purposive sampling. Purposive sampling dilakukan dengan mengambil sampel dari populasi berdasarkan pertimbangan (judgement) tertentu atau jatah (quota) tertentu (Jogiyanto, 2013). Pada penelitian ini kriteria sampel yang digunakan adalah sebagai berikut:

1. Wajib Pajak Badan Kontruksi yang terdaftar di KPP Pratama Langsa.

2. Wajib Pajak Badan Kontruksi yang berbentuk Perseroan Terbatas (PT) yang terdaftar di KPP Pratama Langsa.

3. Wajib Pajak Badan Kontruksi yang telah beroperasi lebih dari 5 tahun.

Sumber data dari penelitian ini adalah data primer dengan cara membagikan kuesioner kepada wajib pajak badan yang terdaftar di KPP Pratama Langsa. Kuesioner yang tersebar sebanyak 45. Metode analisis yang digunakan adalah analisis regresi linier berganda dengan rumus:

$$
Y=a+b_{1} X_{1}+b_{2} X_{2}+b_{3} X_{3}+e
$$

Keterangan:

Y =Persepsi wajib pajak badan mengenai tax evasion 


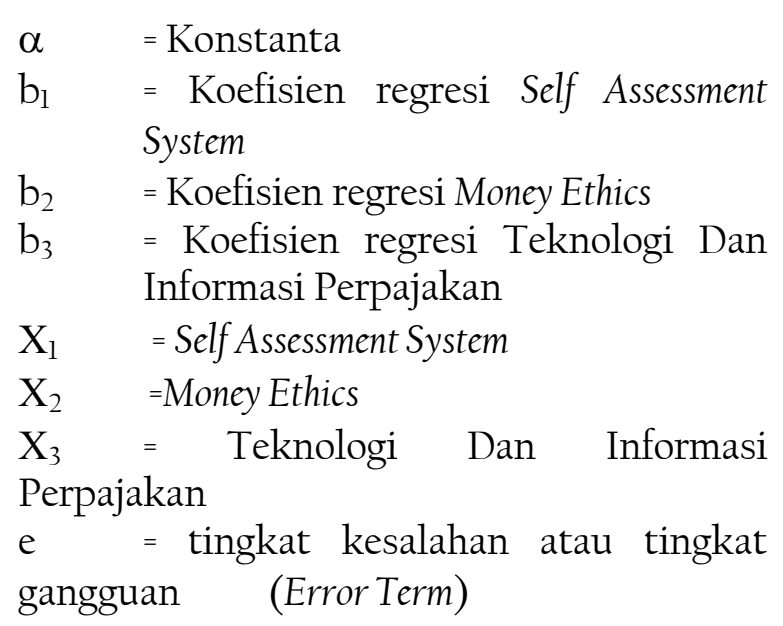

\section{DEFINISI OPERASIONAL DAN PENGU KURAN VARIABEL}

\section{TAXEVASION(Y)}

Menurut Rahayu (2010:149) penggelapan pajak adalah tindakan wajib pajak yang selalu berusaha untuk membayar pajak yang terutang sekecil mungkin dan cenderung melakuakn penyelundupan pajak yang tentunya melanggar peraturan perundang-undangan. Variabel ini diukur menggunakan indikator dari Irma (2013) yaitu:

1. Perilaku penggelapan pajak.

2. Diskriminasi perpajakan.

3. Tarif pajak terlalu tinggi.

4. Hukum yang lemah.

5. Manfaat yang dirasakan wajib pajak.

Instrumen variabel ini terdiri dari 5 item pertanyaan yang diukur dengan 5 poin skala likert, yaitu Sangat Setuju (5), Setuju (4), Netral (3), Tidak Setuju (2), Sangat Tidak Setuju (1).

\section{SELF ASSESSMENT SYSTEM $\left(\mathrm{X}_{1}\right)$}

Self Assessment System adalah suatu sistem perpajakan yang memberi kepercayaan kepada wajib pajak untuk memenuhi dan melaksanakan sendiri kewajiban dan hak perpajakannya dengan cara menghitung, memperhitungkan, menyetor dan melaporkan sendiri jumlah pajak yang dibayar ke negara (Ilyas dan Burton, 2012).

$\begin{array}{crr}\text { Pengukuran } & \text { variabel ini } \\ \text { menggunakan } & \text { indikator } & \text { yang }\end{array}$ dikembangkan oleh Friskianti (2014) yaitu:

1. Mendaftar sebagai wajib pajak.

2. Menghitung pajak terutang oleh wajib pajak.

3. Menyetor pajak terutang oleh wajib pajak.

4. Pelaporan Surat Pemberitahuan (SPT) dilakukan oleh wajib pajak.

Instrumen variabel ini terdiri dari 4 item pertanyaan yang diukur dengan 5 poin skala likert, yaitu Sangat Setuju (5), Setuju (4), Netral (3), Tidak Setuju (2), Sangat Tidak Setuju (1).

\section{MONEY ETHICS $\left(\mathrm{X}_{2}\right)$}

Money Ethics adalah pandangan seseorang terhadap uang. Seseorang yang memiliki etika uang (money ethics) yang tinggi atau disebut juga dengan cinta uang maka mereka akan meletakkan kepentingan yang lebih tinggi terhadap uang dan secara etika kurang peka dibandingkan orang yang memiliki money ethics yang rendah.

\begin{tabular}{lr}
\multicolumn{1}{c}{ Pengukuran } & variabel ini \\
menggunakan & indikator yang \\
dikembangkan oleh Basri (2014) yaitu: &
\end{tabular}

1. Faktor penting uang.

2. Memiliki etika uang yang tinggi.

3. Uang akar segala kejahatan.

4. Merasa rugi akan membayar pajak.

5. Kepuasan terhadap gaji.

Instrumen variabel ini terdiri dari 5 item pertanyaan yang diukur dengan 5 poin skala likert, yaitu Sangat Setuju (5), Setuju (4), Netral (3), Tidak Setuju (2), Sangat Tidak Setuju (1).

\section{TEKNOLOGI DAN INFORMASI PERPAJAKAN $\left(\mathrm{X}_{3}\right)$ \\ Teknologi dan informasi perpajakan} merupakan teknologi dan informasi yang 
digunakan fiskus dalam membantu proses perpajakan. Modernisasi layanan perpajakan yang dilakukan pemerintah saat ini diharapkan dapat meningkatkan kualitas layanan, sehingga diharapkan kepatuhan wajib pajak dalam membayar pajak terhutangnya meningkat dikarenakan dipermudahkannya cara pembayaran dan pelaporan pajak.

Menurut Ayu (2009) teknologi dan informasi perpajakan diukur menggunakan indikator sebagai berikut:

1. Ketersediaan teknologi yang berkaitan dengan perpajakan.

2. Memadainya teknologi yang berkaitan dengan pajak.

3. Akses informasi perpajakan yang mudah

4. Pemanfaatan fasilitas teknologi dan informasi perpajakan.

Instrumen variabel ini terdiri dari 2 item pertanyaan yang diukur dengan 5 poin skala likert, yaitu Sangat Setuju (5), Setuju (4), Netral (3), Tidak Setuju (2), Sangat Tidak Setuju (1).

\section{HASIL PENELITIAN DAN PEMBAHASAN}

\section{Gambaran Umum Responden}

Data dalam penelitian ini diperoleh dari penyebaran kuesioner kepada 45 orang responden yaitu wajib pajak badan kontruksi yang terdaftar di KPP Pratama Langsa. Untuk menghitung data tersebut penulis penggunakan alat bantu Statistical Package for Social Science (SPSS). Dengan menggunakan SPSS, langkah pertama yang dilakukan adalah menghitung frekuensi dari pada karakteristik responden yang terdiri dari usia, jenis kelamin, pendidikan terakhir. Responden berdasarkan usia diklasifikasikan menjadi 4 bagian yaitu: 1 . <25 tahun; 2. 26-35 tahun; 3. 36-45 tahun dan 4. 446 tahun. Responden yang berusia di bawah 25 tahun berjumlah 2 orang atau $4,4 \%$, responden yang berusia antara 26 sampai 35 tahun sebanyak 19 orang atau $42,2 \%$, dan responden yang berusia antara 36 sampai 45 tahun sebanyak 24 orang atau 53,3\%. Maka dapat disimpulkan bahwa responden terbanyak berusia antara 36 sampai 45 tahun. Responden yang berjenis kelamin laki-laki berjumlah 27 orang atau $60,0 \%$ dan responden yang berjenis kelamin perempuan berjumlah 18 orang atau $40,0 \%$. Maka dapat disimpulkan bahwa responden yang berjenis kelamin laki-laki lebih banyak dari responden yang berjenis kelamin perempuan. Pendidikan terakhir responden yaitu sebanyak 21 orang responden atau 46,7\% berpendidikan Diploma, sebanyak 18 orang responden atau $40,0 \%$ berpendidikan Sl dan 6 orang responden atau 13,3\% adalah berpendidikan lainnya. Maka dapat disimpulkan bahwa responden terbanyak yaitu lulusan Diploma.

\section{HASIL PENGUJIAN KUALITAS DATA}

\section{Hasil Uji Validitas}

Pengujian validitas dari instrumen penelitian dilakukan dengan menghitung angka korelasional atau rhitung dari nilai jawaban tiap responden untuk tiap butir pertanyaan, kemudian dibandingkan dengan $r_{\text {tabel }}$. Nilai $r_{\text {tabel }}=0,2940$, didapat dari jumlah DF (n) - 2, atau $45-2=43$, tingkat signifikansi $5 \%$, maka didapat $\mathrm{r}_{\text {tabel }}$ 0,2940. Setiap butir pertanyaan dikatakan valid bila angka korelasional yang diperoleh dari perhitungan lebih besar atau sama dengan $\mathrm{rt}_{\text {abel }}$ (Ghozali, 2011). Berdasarkan hasil pengujian didapatkan bahwa semua pernyataan dikatakan valid, karena koefisien korelasi ( $\left.\mathrm{r}_{\text {hitung }}\right)>\mathrm{r}_{\text {tabel }}$.

\section{Hasil Uji Reliabilitas}

Menurut Ghozali (2011), Uji reliabilitas digunakan untuk mengukur suatu kuesioner yang merupakan indikator dari variabel atau kontruk. Suatu kuesioner dikatakan reliabel jika jawaban seseorang 
terhadap pertanyaan adalah konsisten atau stabil. Pengujian reliabilitas dalam penelitian ini adalah dengan menggunakan rumus alpha sebagai berikut:

1. Jika nilai hasil croanbach alpha $>0,60$; maka butir atau variabel tersebut reliabel.

2. Jika nilai hasil croanbach alpha $<0,60$; maka butir atau variabel tersebut tidak reliabel.

Untuk mengetahui hasil uji reliabilitas dalam penelitian ini, maka dapat dilihat dari tabel di bawah ini:

Tabel 1. Hasil Pengujian Reliabilitas

\begin{tabular}{|l|c|c|c|}
\hline \multicolumn{1}{|c|}{ Variabel } & Alpha & Batasan & Keterangan \\
\hline $\begin{array}{l}\text { Self } \\
\text { Assessment } \\
\text { System }\left(\mathrm{X}_{1}\right)\end{array}$ & 0,774 & 0,60 & Reliabel \\
\hline $\begin{array}{l}\text { Money } \\
\text { Ethics }\left(\mathrm{X}_{2}\right)\end{array}$ & 0,807 & 0,60 & Reliabel \\
\hline $\begin{array}{l}\text { Teknologi } \\
\text { dan } \\
\text { Informasi } \\
\text { Perpajakan } \\
\text { (X) }\end{array}$ & 0,800 & 0,60 & Reliabel \\
\hline $\begin{array}{l}\text { Persepsi } \\
\text { Wajib } \\
\text { Pajak } \\
\text { Badan } \\
\text { Mengenai } \\
\begin{array}{l}\text { Tax Evasion } \\
\text { (Y) }\end{array}\end{array}$ & 0,834 & 0,60 & Reliabel \\
\hline
\end{tabular}

Sumber: Hasil Penelitian, 2018

\section{HASIL UJI ASUMSI KLASIK} Hasil Uji Normalitas

Uji normalitas bertujuan untuk menguji apakah dalam suatu model regresi linear berganda variabel bebas dan variabel terikat keduanya mempunyai distribusi normal atau tidak. Model regresi yang baik adalah memiliki distribusi data normal atau mendekati normal. Uji normalitas dapat diketahui dengan melihat normal probability plot. Distribusi normal akan membentuk satu garis lurus diagonal dan ploting data residual akan dibandingkan dengan garis diagonal. Jika distribusi data residual normal, maka titik-titik yang menggambarkan data akan mengikuti garis diagonalnya.

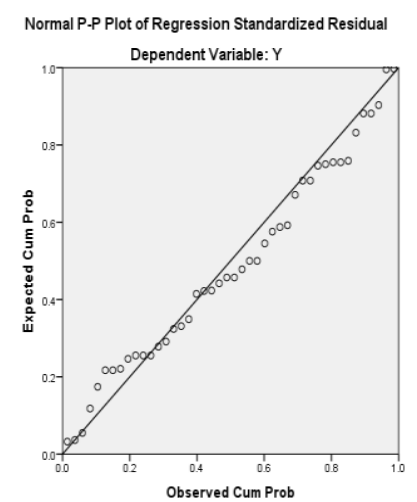

Gambar 1. Normal P-P Plot Regression

\section{Hasil Uji Kolmogorov Smirnov}

Uji kolmogorov-smirnov merupakan pengujian ststistis non-parametric yang paling mendar dan paling banyak digunakan, uji ini digunakan untuk menguji "goodness of fit" antar distribusi sampel dan distibusi lainnya.

Tabel 2. Uji Kolmogorov Smirnov

\begin{tabular}{|ll|r|}
\hline & & $\begin{array}{r}\text { Unstanda } \\
\text { rdized } \\
\text { Residual }\end{array}$ \\
\hline $\mathrm{N}$ & Mean & .0000000 \\
Normal & Std. & 1.10587276 \\
Parameters & a,b & Deviation \\
& Absolute & .097 \\
Most Extreme & .097 \\
Differences & Positive & .095 \\
& Negative & .097 \\
Test Statistic & & $.200^{\mathrm{c}, \mathrm{d}}$ \\
\hline
\end{tabular}

a. Test distribution is Normal.

Sumber: Hasil Penelitian, 2018

Berdasarkan Tabel one-sample kolmogorov-smirnov test, menunjukkan bahwa 
nilai asymp. Sig. (2-tailed) >0,05 maka data berdistribusi normal.

\section{Hasil Uji Multikolinieritas}

Uji multikolinearitas bertujuan untuk menguji apakah dalam model regresi ditemukan adanya korelasi antara variabel bebas (independen). Untuk mendeteksi ada tidaknya gejala multikolinearitas antara variabel independen, dapat dilihat dari nilai tolerance dan variance inflation factor (VIF).

\begin{tabular}{|l|r|c|}
\hline \multirow{2}{*}{ Model } & \multicolumn{2}{|c|}{ Collinearity Statistics } \\
\cline { 2 - 3 } & Tolerance & VIF \\
\hline (Constant) & .499 & \\
X1 & .352 & 2.003 \\
X2 & .261 & 3.837 \\
X3 & .261 & \\
\hline
\end{tabular}

Kriteria pengujian adalah apabila nilai tolerance > 0,10 atau sama dengan nilai VIF «10 maka ada indikasi tidak terjadi multikolinearitas. Hasil pengujian multikolinearitas dari masing-masing variabel independen dapat dilihat pada tabel di bawah ini:

\section{Tabel 3. Uji Multikolinieritas}

Berdasarkan tabel di atas, maka dapat diketahui nilai toleransi dan nilai VIF untuk masing-masing variabel penelitian adalah sebagai berikut:

a. Nilai VIF untuk variabel $\left(\mathrm{X}_{1}\right)$ sebesar $2,003<10$ dan nilai toleransi sebesar $0,499>0,10$ sehingga variabel $\left(X_{1}\right)$ dinyatakan tidak terjadi gejala multikolinearitas.

b. Nilai VIF untuk variabel $\left(\mathrm{X}_{2}\right)$ sebesar $2,842<10$ dan nilai toleransi sebesar $0,352>0,10$ sehingga variabel $\left(\mathrm{X}_{2}\right)$ dinyatakan tidak terjadi gejala multikolinearitas.

c. Nilai VIF untuk variabel $\left(\mathrm{X}_{3}\right)$ sebesar $3,837<10$ dan nilai toleransi sebesar
$0,261>0,10$ sehingga variabel $\left(X_{3}\right)$ dinyatakan tidak terjadi gejala multikolinearitas.

\section{Hasil Uji Heteroskedastisitas}

Uji heterokedastisitas digunakan untuk menguji apakah dalam sebuah model regresi terjadi ketidaksamaan varian. Model regresi yang baik adalah yang tidak terjadi heterokedastisitas. Ghozali (2006:125) mengungkapkan bahwa uji heteroskedastisitas bertujuan untuk menguji apakah terjadi ketidaksamaan varians dari residual suatu pengamatan ke pengamatan yang lain dalam model regresi. Untuk mendeteksi adanya heterokedastisitas dapat dilakukan dengan menggunakan scatter plot. Apabila tidak terdapat pola yang teratur, maka model regresi tersebut bebas dari masalah heterokedastisitas. Hasil pengujian heterokedastisitas dengan metode scatter plot dapat di lihat pada gambar 2 sebagai berikut:

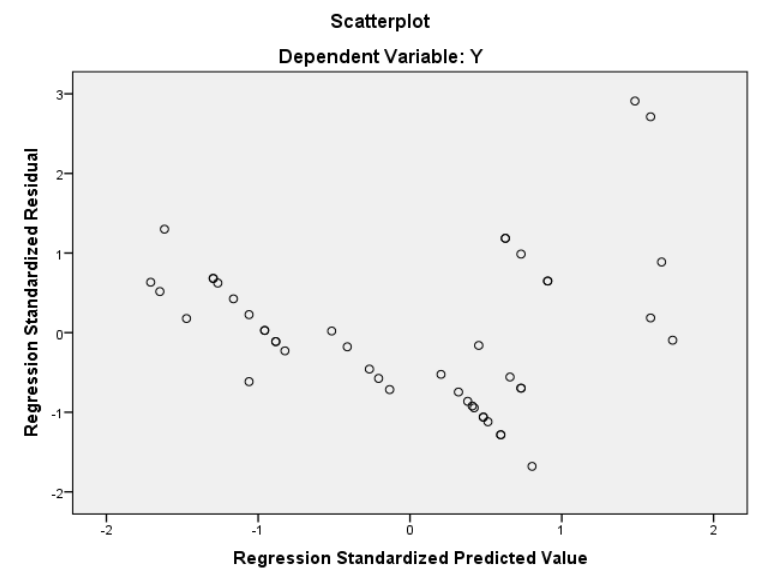

Gambar 2. Hasil Pengujian Heteroskedastisitas

Dari gambar di atas terlihat bahwa titik yang terdapat pada grafik scatterplot menyebar secara acak serta tersebar baik di atas maupun di bawah angka 0 pada sumbu Y. Hal ini dapat disimpulkan bahwa tidak terjadi heteroskedastisitas pada model 
regresi, sehingga model regresi layak dipakai untuk memprediksi variabel dependen berdasarkan masukkan variabel independen.

\section{Hasil Analisis Regresi Linear Berganda}

Penelitian ini bertujuan untuk mengetahui pengaruh Pengaruh Self Assessment System, Money Ethics, dan Teknologi dan Informasi Perpajakan Terhadap Persepsi Wajib Pajak Badan Mengenai Tax Evasion. Hasil analisis linear berganda dengan program SPSS versi 22.0 dapat dilihat pada tabel 4. sebagai berikut.

Tabel 4. Hasil Analisis Regresi Linear Berganda

Berdasarkan tabel 4. di atas, maka dapat dibentuk persamaan regresi linear berganda sebagai berikut:

$\mathrm{Y}=\mathrm{a}+\mathrm{b}_{1} \mathrm{X}_{1}+\mathrm{b}_{2} \mathrm{X}_{2}+\mathrm{b}_{3} \mathrm{X}_{3}+\mathrm{e}$

$Y=8,309-0,218 X_{1}+0,238 X_{2}+1,150 X_{3}+e$

Hasil Pengujian Hipotesis dan Pembahasan

Tabel 5. Hasil Uji Hipotesis

\begin{tabular}{|c|r|c|c|c|c|}
\hline $\begin{array}{c}\text { Hipote } \\
\text { sis }\end{array}$ & $t_{\text {hitung }}$ & $t_{\text {tabel }}$ & Sig. & $\begin{array}{c}\text { Al } \\
\text { ph } \\
\mathrm{a}\end{array}$ & Ket. \\
\hline $\mathrm{H}_{1}$ & $\begin{array}{r}2,23 \\
6\end{array}$ & 1,681 & 0,031 & $\begin{array}{c}0.0 \\
5\end{array}$ & $\begin{array}{c}\text { Diterim } \\
\mathrm{a}\end{array}$ \\
\hline $\mathrm{H}_{3}$ & 2,671 & 1,681 & 0,011 & $\begin{array}{c}0.0 \\
5\end{array}$ & $\begin{array}{c}\text { Diterim } \\
\mathrm{a}\end{array}$ \\
\hline $\mathrm{H}_{3}$ & $\begin{array}{r}3,64 \\
9\end{array}$ & 1,681 & 0,001 & $\begin{array}{c}0.0 \\
5\end{array}$ & $\begin{array}{c}\text { Diterim } \\
\mathrm{a}\end{array}$ \\
\hline
\end{tabular}

$\mathrm{H}_{1}$ : self assessmet system berpengaruh terhadap persepsi wajib pajak badan mengenai tax evasion

Secara parsial (uji t) yang diperoleh dari nilai $t_{\text {hitung }}$ pada persamaan regresi linear berganda menyatakan bahwa self assessment system berpengaruh terhadap persepsi wajib pajak badan mengenai tax evasion, dikarenakan thitung sebesar $-2,236$ dan $t_{\text {tabel }}=1,681$ dimana $t_{\text {hitung }}>t_{\text {tabel }}$ dengan nilai signifikansi 0,031 di bawah 0,05 . Sehingga hipotesis pertama $\left(\mathrm{H}_{1}\right)$ diterima.

Dengan demikian, dapat dikatakan bahwa self assessment system berpengaruh secara parsial terhadap persepsi wajib pajak badan mengenai tax evasion. Hal ini membuktikan bahwa self assessment system memiliki korelasi terhadap persepsi wajib

\begin{tabular}{|c|c|c|c|c|}
\hline Variabel & $\begin{array}{l}\text { Coefficien } \\
\text { ts Regresi }\end{array}$ & $\begin{array}{c}t_{\text {hitun }} \\
\mathrm{g}\end{array}$ & $\begin{array}{c}\mathrm{t}_{\mathrm{tab}} \\
\mathrm{el}\end{array}$ & Sig. \\
\hline Constant & 8.309 & $\begin{array}{l}2.95 \\
7\end{array}$ & $\begin{array}{l}1.6 \\
81\end{array}$ & $\begin{array}{l}.00 \\
5\end{array}$ \\
\hline $\mathrm{Xl}$ & -.218 & $\begin{array}{c}- \\
2.23 \\
6\end{array}$ & $\begin{array}{l}1.6 \\
81\end{array}$ & $\begin{array}{c}.03 \\
1\end{array}$ \\
\hline $\mathrm{X} 2$ & .238 & 2.671 & $\begin{array}{l}1.6 \\
81\end{array}$ & .011 \\
\hline $\mathrm{X} 3$ & 1.150 & $\begin{array}{c}3.64 \\
9 \\
\end{array}$ & $\begin{array}{l}1.6 \\
81 \\
\end{array}$ & $\begin{array}{c}.00 \\
1\end{array}$ \\
\hline $\begin{array}{c}\mathrm{DF}=45-2= \\
43\end{array}$ & $\begin{array}{l}\mathrm{R}=0.903 \\
\mathrm{R}^{2}=0.816 \\
\text { Adjusted } \\
\mathrm{R}^{2}=0.802\end{array}$ & \multicolumn{3}{|c|}{$\begin{array}{l}F_{\text {hitung }}=60.484 \\
F_{\text {tabel }}=2.83\end{array}$} \\
\hline
\end{tabular}

pajak badan mengenai tax evasion. Sistem pemungutan pajak dengan menggunakan self assessment system dimana wajib pajak dengan sukarela untuk mendaftarkan diri, menghitung, menyetor dan melaporkan jumlah pajak yang terutang, sehingga wajib pajak dituntut untuk bersikap jujur dan patuh dalam pelaporan jumlah kewajiban perpajakannya dengan begitu wajib pajak tersebut telah berpartisipasi dalam menyukseskan pelaksanaan self assessment system. Di KPP Pratama Langsa khususnya wajib pajak badan telah melaksanakan kewajiban perpajakannya dengan tepat waktu dan jujur, hal ini terlihat dari peningkatan jumlah wajib pajak yang mendaftarkan diri yaitu pada tahun 2016 
berjumlah 8.532 wajib pajak badan, dan pada tahun 2017 terjadi peningkatan yaitu sebanyak 9.179 wajib pajak badan. Hal ini menunjukkan bahwa respon wajib pajak badan terhadap pelaksanaan self assessment system sangat baik. Semakin baik pelaksanaan self assessment system, dimana tingkat kebenaran menghitung, ketepatan menyetor serta mengisi dan melaporkan SPT baik, maka tindakan tax evasion dapat dihindari.

Hasil penelitian ini sesuai dengan Mira (2016), dan Suwandhi (2010) yang menyatakan bahwa self assessment system berpengaruh negatif dan signifikan terhadap tax evasion. Semakin baik wajib pajak menerapkan self assessment system, maka kecenderungan tindakan untuk melakukan tindakan tax evasion oleh wajib pajak akan semakin berkurang. Artinya apabila wajib pajak dapat menerapkan self assessment system (menghitung, membayar dan melaporkan sendiri kewajiban pajaknya) dengan benar dan tepat waktu maka pemenuhan kewajiban membayar pajak akan semakin baik juga.

\section{$\mathrm{H}_{2}$ : money ethhics berpengaruh terhadap persepsi wajib pajak badan mengenai tax evasion}

Secara parsial (uji t) yang diperoleh dari nilai $t_{\text {hitung pada persamaan regresi }}$ linear berganda menyatakan bahwa money ethics berpengaruh signifikan (nyata) terhadap persepsi wajib pajak badan mengenai tax evasion, dikarenakan $t_{\text {hitung }}$ sebesar 2,671 dan $t_{\text {tabel }}=1,681$ dimana $t_{\text {hitung }}$ > $t_{\text {tabel }}$ dengan nilai signifikansi 0,011 dibawah 0,05. Sehingga hipotesis kedua $\left(\mathrm{H}_{2}\right)$ diterima. Hal ini membuktikan bahwa money ethics korelasi terhadap persepsi wajib pajak badan mengenai tax evasion. Tinggi rendahnya money ethics pada dalam diri seseorang yang akan mempengaruhi seseorang tersebut melakukan tax evasion.
Masih ada wajib pajak yang merasa rugi untuk melakukan kewajibannya membayar pajak dengan alasan mereka tidak merasakan manfaat ketika sudah membayar pajak.

Hasil penelitian ini mendukung hasi penelitian Lau, Choe, dan Tan (2013) dan Rosianti (2014) menemukan hubungan yang positif antara money ethics dengan tax evasion. Ketika seseorang menekankan pada pentingnya uang dan memperoleh kekayaan mereka akan merasa bahwa tax evasion dapat diterima. Seseorang yang sangat termotivasi oleh uang atau yang menempatkan uang sebagai prioritas utama akan percaya bahwa tax evasion adalah tindakan yang baik. Semakin tinggi tingkat kecintaan sesorang terhadap uang, maka semakin tinggi peluang seseorang melakukan tindakan tax evasion.

\section{$\mathrm{H}_{3}$ : teknologi dan informasi perpajakan berpengaruh terhadap persepsi wajib pajak badan mengenai tax evasion}

Secara parsial (uji t) yang diperoleh

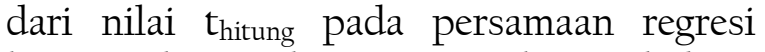
linear berganda menyatakan bahwa teknologi dan informasi perpajakan berpengaruh signifikan (nyata) terhadap persepsi wajib pajak badan mengenai tax evasion, dikarenakan thitung sebesar 3,649 dan $t_{\text {tabel }}=1,681$ dimana $t_{\text {hitung }}>t_{\text {tabel }}$ dengan nilai signifikansi 0,001 dibawah 0,05. Sehingga hipotesis ketiga $\left(\mathrm{H}_{3}\right)$ diterima. Hal ini membuktikan bahwa teknologi dan informasi perpajakan memiliki korelasi terhadap persepsi wajib pajak badan mengenai tax evasion. Kesadaran wajib pajak di Langsa terhadap penggunaan teknologi dan informasi perpajakan sudah bisa dikatakan baik. Hal ini ditandai dengan melihat sudah banyak wajib pajak yang menggunakan fasilitas-fasilitas perpajakan yang ditawarkan oleh ditjen pajak. Dengan 
adanya fasilitas perpajakan yang diberikan oleh ditjen pajak akan memudahkan wajib pajak untuk melakukan kewajiban perpajakannya.

Hasil penelitian mendukung hasil penelitian yang dilakukan oleh Permatasari (2013) dan Wahyuningsih (2015) bahwa teknologi dan informasi perpajakan berpengaruh secara parsial terhadap tax evasion. Semakin tinggi dan modern teknologi dan informasi perpajakan yang digunakan, semakin tinggi tingkat tax evasion yang dilakukan. Adanya kemudahan teknologi dan informasi perpajakan mengakibatkan adanya oknum-oknum yang ingin membobol data-data pajak (hacker). Kemajuan teknologi dan informasi perpajakan diharapkan membantu wajib pajak dalam melakukan kewajiban perpajakannya, bukan untuk melakukan tindakan-tindakan negatif seperti tax evasion.

\section{Hasil Uji Simultan (Uji F)}

Tabel 6. Hasil Uji F

\begin{tabular}{|l|c|c|c|c|r|}
\hline Model & $\begin{array}{c}\text { Sum of } \\
\text { Square } \\
\text { S }\end{array}$ & Df & $\begin{array}{c}\text { Mean } \\
\text { Square }\end{array}$ & F & Sig. \\
\hline Regress & 234,84 & 3 & 78,282 & 60,48 &, 00 \\
ion & 7 & & $0^{\mathrm{b}}$ \\
Residua & 53,065 & 41 & 1,294 & & \\
1 & & & \\
Total & 287,911 & 44 & & & \\
\hline
\end{tabular}

a. Dependent Variable: y

b. Predictors: (Constant), x3, xl, x2

$\mathrm{H}_{4}$ : self assessment system, money ethics, dan teknologi dan informasi perpajakan berpengaruh terhadap persepsi wajib pajak badan mengenai tax evasion

Berdasarkan Tabel 6 di atas dapat dilihat bahwa nilai $F_{\text {hitung }}>F_{\text {tabel }}$ atau 60,484 > 2,83. Pengujian hipotesis dengan uji $F$ dilakukan dengan membandingkan antara $\mathrm{F}_{\text {hitung }}$ dengan $\mathrm{F}_{\text {tabel. }}$. Dengan demikian berarti secara simultan variabel self assessment system $\left(\mathrm{X}_{1}\right)$, money ethics $\left(\mathrm{X}_{2}\right)$, dan teknologi dan informasi perpajakan $\left(\mathrm{X}_{3}\right)$ terhadap persepsi wajib pajak badan mengenai tax evasion $(\mathrm{Y})$ sehingga hipotesis $\left(\mathrm{H}_{4}\right)$ diterima.

Berdasarkan hasil pengujian tersebut dapat diketahui bahwa ketiga variabel yaitu self assessment system $\left(\mathrm{X}_{1}\right)$, money ethics $\left(\mathrm{X}_{2}\right)$, dan teknologi dan informasi perpajakan $\left(\mathrm{X}_{3}\right)$, mampu memberikan pengaruh terhadap tax evasion. Dengan demikian self assessment system $\left(\mathrm{X}_{1}\right)$, money ethics $\left(\mathrm{X}_{2}\right)$, dan teknologi dan informasi perpajakan (X3), mempunyai pengaruh terhadap persepsi wajib pajak badan mengenai tax evasion.

Hasil penelitian sesuai dengan yang dilakukan oleh Permatasari (2013) bahwa self assessment system dan teknologi dan informasi perpajakan berpengaruh terhadap persepsi wajib pajak badan mengenai tax evasion. Sedangkan money ethics berpengaruh terhadap persepsi wajib pajak badan mengenai tax evasion. Hal ini berarti mendukung penelitian yang dilakukan oleh Lau, Choe, dan Tan (2013).

\section{SIMPULAN DAN SARAN Simpulan}

Berdasarkan pengujian dan hasil peenlitian yang telah dilakukan mengenai Pengaruh Self Assessment System, Money Ethics, dan Teknologi dan Informasi Perpajakan Terhadap Persepsi Wajib Pajak Badan Mengenai Tax Evasion, maka peneliti dapat mengambil keputusan sebagai berikut:

1. Self assessment system berpengaruh terhadap persepsi wajib pajak badan mengenai tax evasion. Dari hasil uji $\mathrm{t}$ maka $\mathrm{H}_{1}$ diterima dan dapat diartikan bahwa secara parsial self assessment system berpengaruh terhadap persepsi wajib pajak badan mengenai tax evasion. Hal ini berarti semakin baik wajib pajak 
menerapkan self assessment system, maka kecenderungan tindakan untuk melakukan tindakan tax evasion oleh wajib pajak akan semakin berkurang.

2. Money ethics berpengaruh terhadap persepsi wajib pajak badan mengenai tax evasion. Dari hasil uji $\mathrm{t}$ maka $\mathrm{H}_{2}$ diterima dan dapat diartikan bahwa secara parsial money ethics berpengaruh terhadap persepsi wajib pajak badan mengenai tax evasion. Ketika seseorang menekankan pada pentingnya uang dan memperoleh kekayaan mereka akan merasa bahwa tax evasion dapat diterima. Seseorang yang sangat termotivasi oleh uang atau yang menempatkan uang sebagai prioritas utama akan percaya bahwa tax evasion adalah tindakan yang baik. Semakin tinggi tingkat kecintaan sesorang terhadap uang, maka semakin tinggi peluang seseorang melakukan tindakan taxevasion.

3. Teknologi dan informasi perpajakan berpengaruh terhadap persepsi wajib pajak badan mengenai tax evasion. Dari hasil uji t maka $\mathrm{H}_{3}$ diterima dan dapat diartikan bahwa secara parsial teknologi dan informasi perpajakan berpengaruh terhadap persepsi wajib pajak badan mengenai tax evasion. Semakin tinggi dan modern teknologi dan informasi perpajakan yang digunakan, semakin tinggi tingkat tax evasion yang dilakukan. Adanya kemudahan teknologi dan informasi perpajakan mengakibatkan adanya oknum-oknum yang ingin membobol data-data pajak (hacker). Kemajuan teknologi dan informasi perpajakan diharapkan membantu wajib pajak dalam melakukan kewajiban perpajakannya, bukan untuk melakukan tindakan-tindakan negatif seperti taxevasion.
4. Self assessment system, money ethics, dan teknologi dan informasi perpajakan berpengaruh secara simultan terhadap persepsi wajib pajak badan mengenai tax evasion. Dari hasil uji $\mathrm{F}$ ini maka $\mathrm{H}_{4}$ diterima dan dapat diartikan bahwa secara bersama-sama atau simultan self assessment system, money ethics, dan teknologi dan informasi perpajakan berpengaruh terhadap persepsi wajib pajak badan mengenai tax evasion.

\section{Saran}

Berdasarkan hasil pembahasan dan kesimpulan mengenai pengaruh self assessment system, money ethics, dan teknologi dan informasi perpajakan terhadap persepsi wajib pajak badan mengenai tax evasion, maka saran yang dapat dikemukakan sebagai berikut:

1. Kepada pihak KPP Pratama Langsa agar meningkatkan tingkat pengawasan dalam pelaksanaan Self Assessment System untuk menekan tindakan tax evasion yang dilakukan wajib pajak.

2. Kepada pihak KPP Pratama Langsa agar intensitas pengutipan pajak ditingkatkan lagi.

3. Kepada pihak KPP Pratama Langsa agar lebih sering memberikan pelatihan atau sosialisasi terkait penggunaan teknologi dan informasi perpajakan.

4. Kepada peneliti selanjutnya agar menambah jumlah responden dan wilayah penelitian sehingga menambah sebuah penelitian yang lebih baik, dan menambahkan jumlah variabel independen yang dapat mempengaruhi penggelapan pajak, seperti ketepatan pengalokasian, pemeriksaan dan budaya yang berbeda. 


\section{DAFTAR PUSTAKA}

Ardyaksa, Theo Kusuma dan Kiswanto. 2014. Pengaruh Keadilan, Tarif Pajak, Ketetapatan Pengalokasian, Kecurangan, Teknologi dan Informasi Perpajakan Terhadap Tax Evasion. Accounting Analysis Journal. Semarang: Universitas Negeri Semarang.

Ayu R, Stephan Dyah dan Rini Hastuti. 2009. Persepsi Wajib Pajak: Dampak Pertentangan Diametral Pada Tax Evasion Dalam Aspek Kemungkinan Terdeteksinya Kecurangan, Keadilan, Ketepatan Pengalokasian, Teknologi Sistem Perpajakan, dan Kecenderungan Personal (Studi Wajib Pajak Orang Pribadi). Dalam Kajian Akuntansi, 1(l): h:1-12. Semarang: UNIKA Soegijapranata.

Dewinta, Rinta Mulia dan Syafruddin. 2012. Pengaruh Persepsi Pelaksanaan Sensus Pajak Nasional dan Kesadaran Perpajakan Terhadap Kepatuhan Wajib Pajak di Lingkungan Kantor Wilayah Direktorat Jenderal Pajak Daerah Istimewa Yogyakarta. Diponegoro Journal of Accounting. Vol. 1. No. 2, Hal: 1-9.

Friskianti, Yossi dan Bestari Dwi Handayani. 2014. Pengaruh Self Assessment System, Keadilan, Teknologi Perpajakan, dan Ketidakpercayaan Kepada Pihak Fiskus Terhadap Tindakan Tax 
Evasion. Accounting Analysis Journal. Semarang: Universitas Negeri Semarang.

Gelapkan Pajak, Asian Agri Dihukum Denda Rp. 2,5 Triliun. 2012. http://www.mongabay.co.id/2012/12/ 28/gelapkan-pajak-asian-agridihukum-denda-rp25-triliun/. Diakses pada 17 Februari 2017.

Khalid, Ansyarif. 2016. Pengaruh Self Assessment System dan Pemeriksaan Terhadap Tax Evasion dengan Moralitas Pajak Sebagai Variabel Moderat Pada KPP Pratama Makassar Utara. Akuntansi Peradaban. Vol. II. No. 1 Juli 2016.

Kiswanto. 2014. Pengaruh Keadilan, Tarif Pajak, Ketetapan Pengalokasian, Kecurangan, Teknologi dan Informasi Perpajakan Terhadap Tax Evasion. Accounting Analysis Journal, AAJ 3 (4), (2014).

Lau, T. C., Choe, K. L., \& Tan, L. P. (2013). The Moderating Effect of Religiosity in the Relationship Between Money Ethics and Tax Evasion. Asian Social Science, 9(11), 213-220.

Mardiasmo. 2013. Perpajakan Edisi Revisi 2013. Yogyakarta: Andi.

Martin, Sony. 2011. Tax Evasion VS Tax Avoidance Studi Kasus Penghindaran dan Penggelapan Pajak. Newyork Tax Consulting. Jakarta

Mukharoroh, Annisa’ul Handayani dan Nur Cahyonowati. 2014. Analisis Faktor-Faktor Yang Mempengaruhi Persepsi Wajib
Pajak Mengenai Penggelapan

Pajak. Diponegoro Journal of Accounting, Vol.3, No.3, Hal:1-7

Nurhamidin, Fransisca Eprilia dkk. 2015. Pengaruh Persepsi Wajib Pajak Orang Pribadi Atas Pelaksanaan Self Assessment System Terhadap Tindakan Tax Evasion Di Kota Gorontalo. Jurusan Akuntansi Universitas Gorontalo.

Permatasari, Inggrid dan Harry Laksito. 2013. Minimalisasi Tax Evasion Melalui Tarif Pajak, Teknologi dan Informasi Perpajakan, Keadilan Sistem Perpajakan, dan Ketetapan Pengalokasian Pengeluaran Pemerintah. Diponegoro Journal of Accounting, Vol. 3, No. 2, Hal: 1-9.

Paramita, A.A Mirah Pradnya dan I Gusti Ayu. 2016. Pengaruh Sistem Perpajakan, Keadilan, Dan Teknologi Perpajakan Pada Persepsi Wajib Pajak Mengenai Penggelapan Pajak. E-Jurnal Akuntansi Vol. 17. 2. Bali: Universitas Udayana.

Rahayu, Siti Kurnia. 2010. Perpajakan Indonesia:Konsep dan Aspek Formal. Yogyakarta:Graha Ilmu.

Rahman, Irma S. 2013. Pengaruh Keadilan, Sistem Perpajakan, Diskriminasi dan Kemungkinan Terjadinya Kecurangan Terhadap Persepsi Wajib Pajak Mengenai Penggelapan Pajak (Tax Evasion). Skripsi Fakultas Ekonomi dan Bisnis Universitas Islam Negeri Syarif Hidayatullah Jakarta.

Rachmadi, Wahyu dan Zulaikha. 2014. Faktor-Faktor Yang 
Mempengaruhi Persepsi Wajib Pajak Orang Pribadi Atas Perilaku Penggelapan Pajak. Diponegoro Journal of Accounting, Vol. 3, No. 2, Hal: $1-9$.

Resmi, Siti. 20ll. Perpajakan: Teori dan Kasus. Edisi 6 Buku l. Jakarta: Salemba Empat.

Rosianti, Camelia dan Yenny Mangoting. 2014. Pengaruh Money Ethics Dengan Intrinsic dan Extrinsic Religiosity Sebagai Variabel Moderating. Tax $\sigma$ Accounting Review, Vol. 4, No. 1, 2014. Surabaya Barat: Universitas Kristen Petra.

Santana, Rio dkk. 2015. Pengaruh Keadilan, Self Assessment System, Diskriminasi dan Teknologi Perpajakan Terhadap Persepsi Wajib Pajak Mengenai Penggelapan Pajak (Tax Evasion). Jurnal. Bukittinggi: Universitas Bung Hatta.

Suwandhi, R.S. 2010. Persepsi Wajib Pajak Orang Pribadi Atas Pelaksanaan Self Assessment System Dalam Keterkaitannya Dengan Tindakan Tax Evasion pada KPP Pratama Bandung Cibeunying. Skripsi. Bandung: Universitas Komputer Indonesia.

Wahyuningsih, Dian Tri. 2015. Minimalisasi Tax Evasion Melalui Tarif Pajak, Teknologi dan Informasi Perpajakan, Keadilan Sistem Perpajakan, dan Ketetapan Pengalokasian Pengeluaran Pemerintah. Jurnal. Semarang: Universitas Dian Niswantoro Semarang. 